\title{
Enhanced Recovery after an Innovative Percutaneous Endoscopic Transforaminal Lumbar Interbody Fusion for the Treatment of Lumbar Spinal Stenosis: A Prospective Observational Study
}

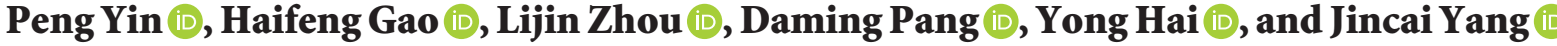 \\ Department of Orthopaedics, Beijing Chao-Yang Hospital, China Capital Medical, Beijing, China \\ Correspondence should be addressed to Yong Hai; yonghaispine@126.com and Jincai Yang; jcyang2018@126.com
}

Received 7 November 2021; Accepted 7 December 2021; Published 20 December 2021

Academic Editor: Jun Zou

Copyright (C) 2021 Peng Yin et al. This is an open access article distributed under the Creative Commons Attribution License, which permits unrestricted use, distribution, and reproduction in any medium, provided the original work is properly cited.

\begin{abstract}
Background. The objective of this study was to investigate the enhanced recovery clinical effects of an innovative percutaneous endoscopic transforaminal lumbar interbody fusion (PE-TLIF) for the treatment of patients with LSS and degenerative instability. Methods. From January 2019 to March 2020, 51 patients with single-segment LSS and degenerative instability were prospectively included in our study (ChiCTR1900020679). The Oswestry Disability Index (ODI), the visual analogue scale (VAS) on lumbar and leg pain (VAS-LBP and VAS-LP), serum creatine kinase (CK), the peak intensity of sulphur hexafluoride microbubble contrast agent (PI), and the maximal cross-sectional area of multifidus muscle (Max-CSA) around the surgical incision were assessed preoperatively, postoperatively, and at regular follow-up. Results. All patients were followed up. The mean postoperative bedridden time was $20.45 \pm 2.66$ hours. The ODI, VAS-LBP, and VAS-LP were improved significantly after operation compared to these data before operation in all the patients $(P<0.05)$. The CK at 1 day after operation was higher compared to the data before the operation $(P<0.05)$, and there was no significant difference on $\mathrm{CK}$ at 1 week after operation $(P>0.05)$. The PI at 1 week after operation was higher compared to this item before operation $(P<0.05)$, and there was no significant difference on PI at 1 month or 3 months after operation $(P>0.05)$. The Max-CSA at 1 week after operation was higher compared to this item before the operation $(P<0.05)$, and there was no significant difference in Max-CSA at 1 month or 3 months after operation compared with before the operation $(P>0.05)$. Conclusions. Our results and systematic review presented the innovative PE-TLIF technique could obtain satisfactory and effective outcomes for the treatment of patients with LSS and degenerative instability. Our PE-TLIF technique also had the ability to decrease the MF injury and obtain an enhanced recovery.
\end{abstract}

\section{Introduction}

Lumbar spinal stenosis (LSS) is the most common type of lumbar degenerative disease for people with low back pain [1]. Several patients need to receive operation treatment due to the inefficiency of conservative treatment to alleviate the severe pain [2]. Conventional posterior lumbar fusion surgery is considered as the standard operation for patients with LSS [3]. However, extensive striping and retraction of muscle and other soft tissue usually caused some approachrelated complications, especially postoperative tremendous back pain [4]; meanwhile, postoperative bedridden time was always extended.

Some studies showed that paravertebral muscle atrophy was clinically related to low back pain $[5,6]$. The multifidus muscle (MF) is an important structure in paravertebral muscles, and MF atrophy is considered to be associated with low back pain [7]. Recently, it was reported that the volume of the multifidus muscle was dramatically decreased after the open posterior lumbar fusion [8]. Hence, it is necessary to perform a minimally invasive lumbar surgery to decrease the injury of the MF and shorten the postoperative rehabilitation period.

Endoscopic lumbar fusion techniques have gradually gained popularity in the past several years, and we have also developed an innovative minimally invasive surgery named percutaneous endoscopic transforaminal lumbar interbody fusion (PE-TLIF) [9].The preliminary results of our technique were satisfactory, but the injury of the MF and enhanced recovery were not evaluated in our previous study. 
Hence, we conducted a prospective observation study on the MF injury via contrast-enhanced ultrasonography after PETLIF for the treatment of patients with LSS to provide evidence of obtaining an enhanced recovery. Meanwhile, we further investigated the clinical effects of PE-TLIF in order to provide good evidence for clinical practice.

\section{Material and Methods}

From January 2019 to March 2020, 51 patients with singlesegment LSS and degenerative instability were included in our study (ChiCTR1900020679). The eligible criteria were as follows: (1) patients with LSS and degenerative instability on L4/5 level; (2) patients treated by PE-TLIF; (3) no lumbar surgery history; (4) no obvious multifidus muscle injury; and (5) no lumbar deformity. The exclusion criteria were as follows: (1) patients were unable to finish the follow-up; (2) patients with other comorbidity could affect the lumbar fusion; and (3) patients with other comorbidity could affect the serum creatine kinase. All patients were told all possible results during the study and signed written consent before the operation. The study was approved by the institutional review board of Beijing Chaoyang Hospital.

Appropriate perioperative assessments were conducted for all patients before the operation. 51 patients were operated by the PE-TLIF technique. There were 37 females and 14 males, and the average age was $58.98 \pm 8.64$ years. Operative level was $\mathrm{L} 4 / 5$. Operation time, intraoperative bleeding volume, postoperative drainage volume, and postoperative bedridden time were recorded. The intervertebral fusion was evaluated via the Bridwell criteria at 6 months after the operation. The Oswestry Disability Index (ODI), visual analogue scale (VAS) on lumbar and leg pain (VAS-LBP and VAS-LP), serum creatine kinase (CK), the peak intensity of sulphur hexafluoride microbubble contrast agent (PI), and the maximal cross-sectional area of multifidus muscle (Max-CSA) around the surgical incision were calculated via contrast-enhanced ultrasonography at 1 week, 1 month, 3 months, and then at final follow-up (Figure 1).

2.1. Surgical Techniques. The patients were in a prone position. General anesthesia or low-dose epidural anesthesia combined with local anesthesia was applied during the PETLIF surgery. The C-arm fluoroscope was employed to confirm the surgical lumbar segment. The primary guide pin was inserted into the pedicle of the symptomatic side, and a specially designed SAP guider was used to put the secondary guide pin into fixation at the superior articular process (SAP). Then, dilating cannulas were inserted gradually through the secondary guide pin. A hook-shaped front of the cannula was applied to ensure the majority of SAP was excised safely by trepan (Figure 2). The endoscope system was connected after the working channel was placed through Kambin's triangle. The canal and nerve root were decompressed with the surveillance of the endoscopy (Figure 3), and then the complete endplate preparation was performed (Figure 4). The acceptable extent of endplate preparation under endoscopy was the appearance of hemic exudation from the bone endplate. An expandable cage (Shanghai Reach Medical Instrument Co., Ltd, Shanghai, China) with iliac bone autograft was then inserted through the working channel. Iliac bone autografting and adequate bone graft size ( $\geq 5 \mathrm{~mm}^{3}$ per intervertebral space). The nerve root was confirmed to be totally relieved via endoscopy once again. Finally, four pedicle screws and two rods were inserted percutaneously. The active bleeding was stopped under the surveillance of endoscopy, and the incisions were sutured. More details on the PE-TLIF technique were described in our previous study [9].

2.2. Statistical Analysis. The data were analyzed by SPS 17.0 software with chi-square and Fisher's exact test for nominal data and an independent $t$-test in continuous data. A statistically significant difference was determined when $P<0.05$.

\section{Results}

All patients underwent PE-TLIF surgery successfully. The mean operation time was $202.65 \pm 27.52$ minutes. The average intraoperative bleeding volume was $125.20 \pm 40.41 \mathrm{ml}$. The average incision length was $8.54 \pm 2.22 \mathrm{~cm}$. The mean postoperative bedridden time was $20.45 \pm 2.66$ hours.

All patients were followed up, and the average follow-up period was $18.70 \pm 4.54$ months. The ODI at 3 months after the operation and at final follow-up were improved significantly compared to the data before operation in all patients $(P<0.05)$. The VAS-LBP and VAS-LP at 1 week, 3 months, and 6 months after the operation and at final follow-up improved significantly compared to these data before operation in all the patients $(P<0.05)$ (Table 1 and Figure 5).

The $\mathrm{CK}$ at 1 day after the operation was higher compared to the data before the operation $(P<0.05)$, and there was no significant difference in $\mathrm{CK}$ at 1 week after the operation $(P>0.05)$. The PI at 1 week after the operation was higher compared to this item before the operation $(P<0.05)$, and there was no significant difference in PI at 1 month, 3 months after the operation, and also at final follow-up compared to this item before the operation $(P>0.05)$. The Max-CSA at 1 week after the operation was higher compared to this item before the operation $(P<0.05)$, and there was no significant difference in Max-CSA at 1 month 3 months after the operation, and also at final follow-up compared with this item before the operation $(P>0.05)$. More details are listed in Table 2.

All the patients finished the intervertebral fusion at 6 months after the operation. According to the Bridwell criteria, 23 patients were rated as Grade 1, 24 patients as Grade II, and 4 patients as Grade III. One patient suffered temporary knee tendon hyperreflexia after surgery and recovered within 24 hours after surgery.

\section{Discussion}

This is the first prospective observation study on the MF injury via contrast-enhanced ultrasonography after PE-TLIF for the treatment of patients with LSS and degenerative 


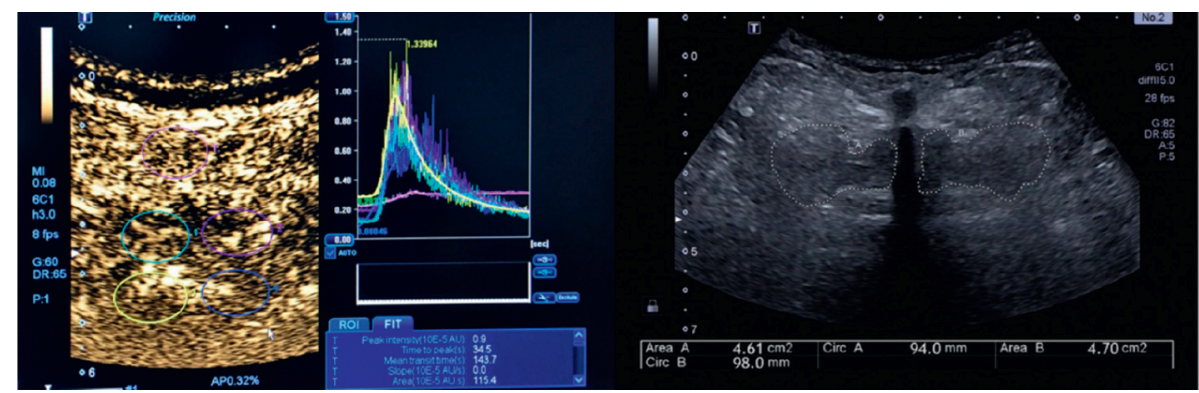

FIGURE 1: Contrast-enhanced ultrasonography was used to demonstrate the blood perfusion of the multifidus muscle microcirculation.

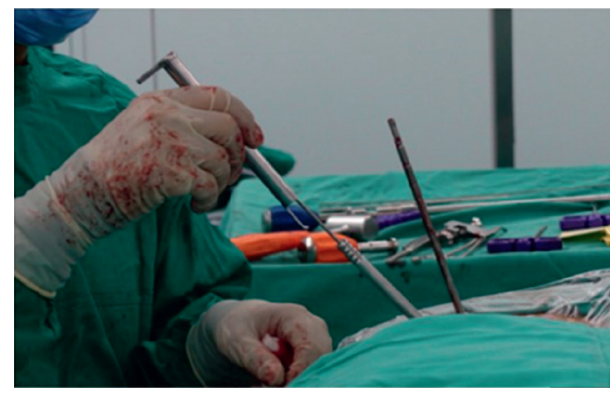

(a)

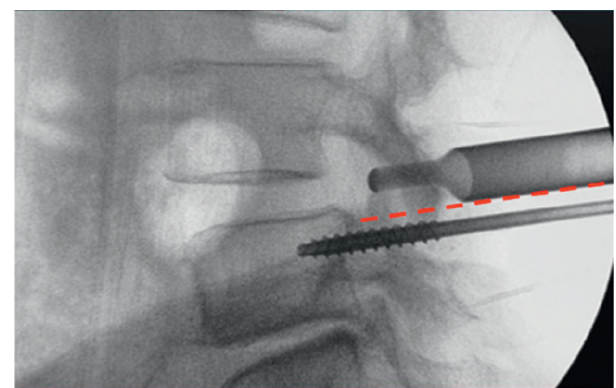

(c)

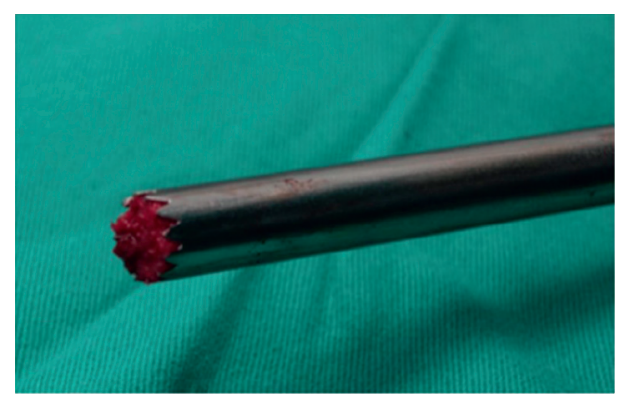

(e)

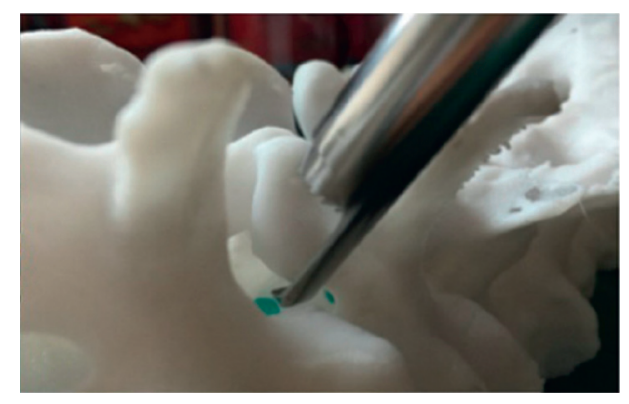

(b)

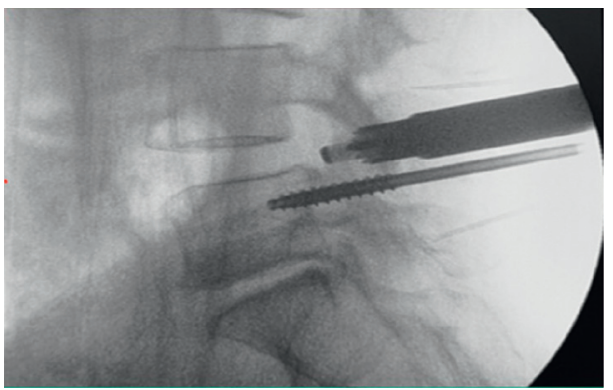

(d)

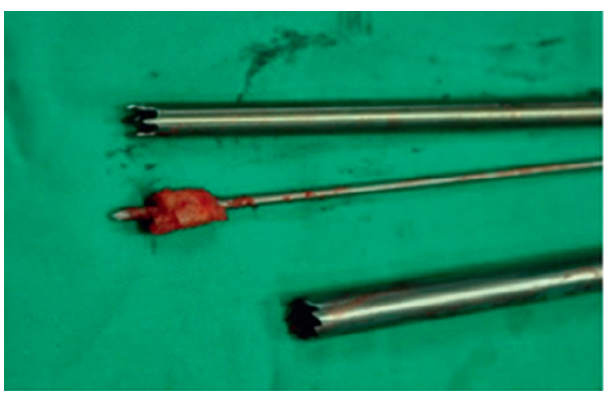

(f)

FIGURE 2: Resection method of the superior articular process. The hook-shaped protective sleeve clings to the lateral periosteum of the superior articular process, reaches the ventral side of the articular process, protects the exiting nerve root and can control the cutting depth of the trephine at the same time, protects the dura mater and nerve root, and rotates the trephine to remove the superior articular process.

instability at present. Our present results showed that the MF injury in the PE-TLIF technique could be recovered at 1 month after the operation, and the CK at 1 week after the operation was restored to the status before the surgery. The ODI and VAS were significantly improved for all the patients via the PE-TLIF surgery. The mean postoperative bedridden time was less than 24 hours.
The MF plays an important role in the preservation of lumbar segmental stability and stiffness [10]. The MF is the most medial component of the lumbar paraspinal muscles and is only innervated by the medial branch of the dorsal ramus, without intersegmental nerve supply [11]. Hence, iatrogenic denervation of the MF usually occurs during the dissection and retraction in conventional posterior lumbar 


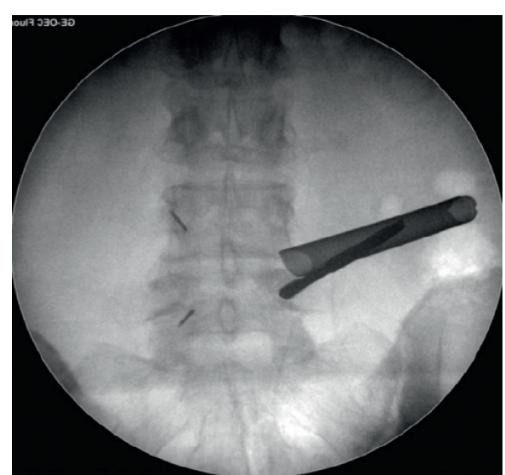

(a)

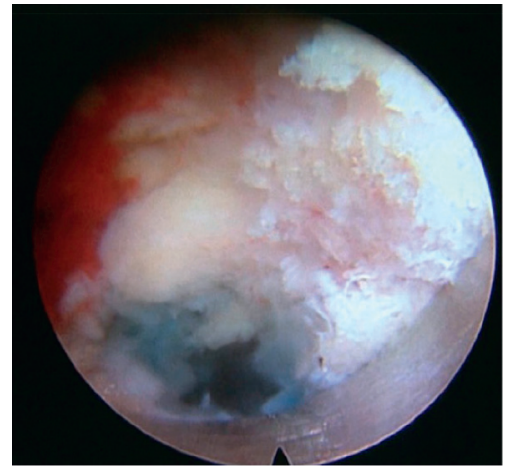

(d)

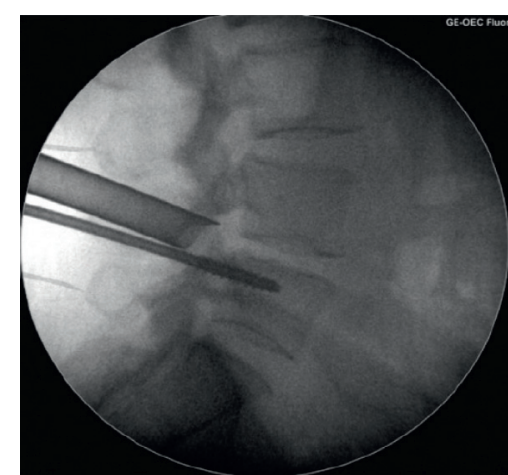

(b)

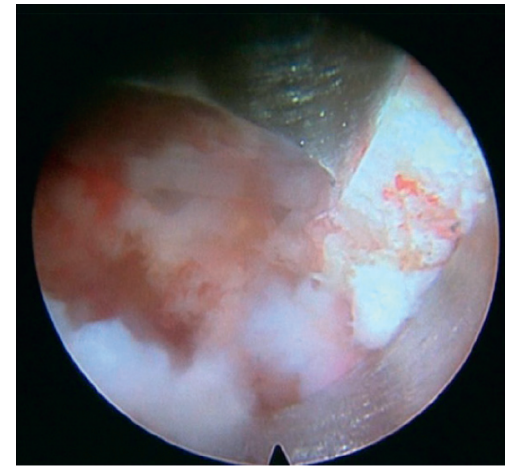

(e)

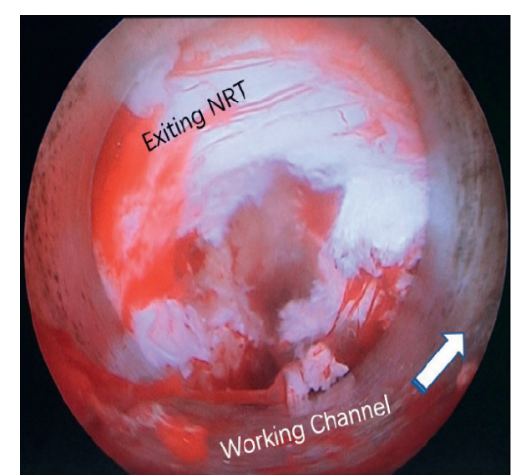

(c)

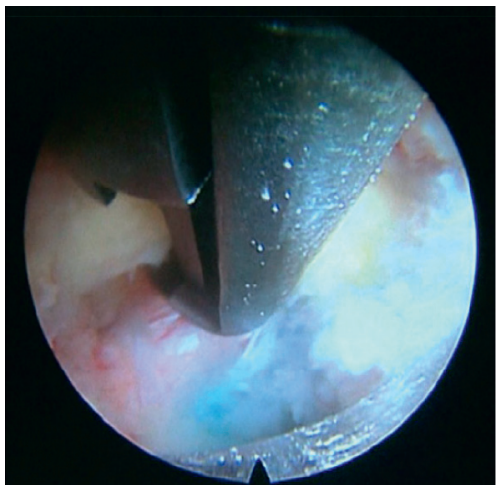

(f)

FIgURE 3: Full-endoscopic decompression. $(\mathrm{a}, \mathrm{b})$ The optimal position of the working channel is confirmed under the fluoroscopy of the Carm. In anteroposterior fluoroscopy, the front end of the working channel reaches the outer edge of the vertebral body. In lateral fluoroscopy, the front end of the working channel reaches the posterior edge of the vertebral body (image from the other patient). (c) Place the endoscope, the blue disc is easy to find and the nerve root should be protected carefully. Confirm the exiting nerve root under endoscopy and protect the nerve root by rotating the tongue-shaped working channel. Remove the surrounding nucleus pulposus tissue and relieve the nerve root. (d) The stump of the superior articular process after trephine cutting. (e) The stump is dealt with an osteotome under an endoscope to ensure complete resection of the superior articular process until the upper wall of the pedicle is exposed. (f) The laminar rongeur is used to remove the hyperplastic ligamentum flavum and reveal the transversing nerve roots under the endoscope.

fusion surgery. Some researchers believed that postoperative muscle atrophy was related to iatrogenic denervation of the paraspinal muscles during the operation [12]. The MF atrophy was mostly associated with postoperative low back pain [8]. Therefore, most spine surgeons demonstrate that decreasing the MF injury is vital for the improvement of the postoperative functional outcomes and shortening the rehabilitation period. Hence, minimizing the MF injury during the surgery gradually became a pursuing goal.

Minimally invasive spine surgeries (MISS) have gained popularity to decrease the muscle-related injury on the conventional open surgeries. Schwender et al. first described the minimally invasive transforaminal lumbar interbody fusion (MIS-TLIF), and the technique showed the potential advantages in the aspect of soft tissue injury over conventional open techniques [13]. However, the placement of screws in the MIS-TLIF technique is very similar to conventional open surgeries, so the medial branch of the dorsal ramus is usually injured, which could increase the possibility of the MF atrophy. Regev et al. believed that percutaneous screw placement was able to decrease the indirect injury of the medial branch nerve from $84 \%$ to $20 \%$ [14].Therefore, more and more surgeons have begun to attempt endoscopic lumbar fusion techniques with percutaneous screw fixation for lumbar degenerative diseases.

In our study, we developed an innovative endoscopic fusion technique named PE-TLIF, and the initial clinical results were favorable [9]. Postoperative serum CK level was considered as a marker of intraoperative related muscle injury [15]. The CK level was recovered to the preoperative level in all the patients, which was consistent with the previous report [16]. The minimally invasive technique could reduce the injury extent of the muscle. CSA was rated as a valuable indicator of MF injury. Some studies showed that the postoperative CSA of the MF was significantly smaller than the preoperative status $[16,17]$. In our study, there was no difference in the Max-CSA via contrast-enhanced ultrasonography between the preoperative level and the level at 1 month after the PE-TLIF technique. We also investigated the PI through contrast-enhanced ultrasonography, and the PI was restored to the preoperative level at 1 month after the PE-TLIF technique. The CK, Max-CSA, and PI were higher than the preoperative items in the early postoperative stage, which was mostly associated with the 


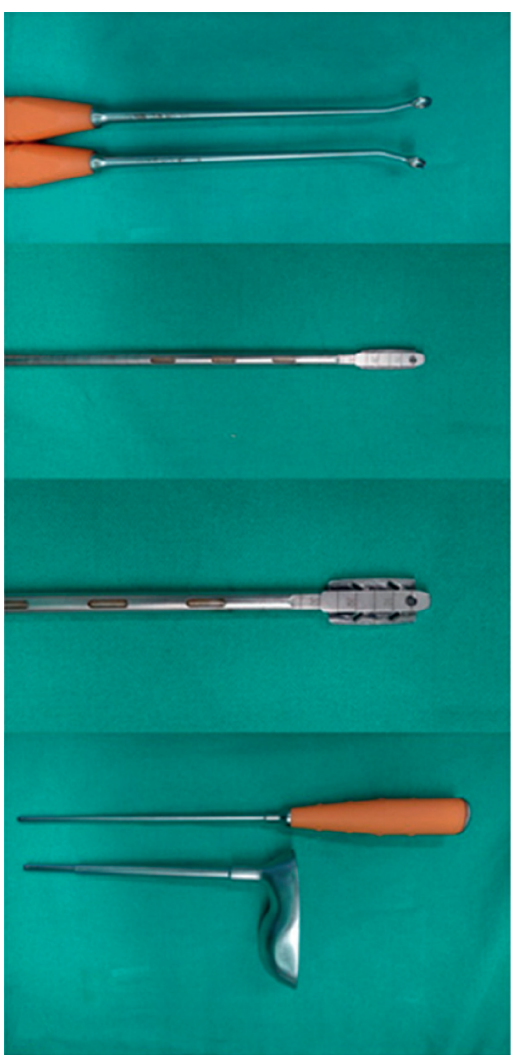

(a)
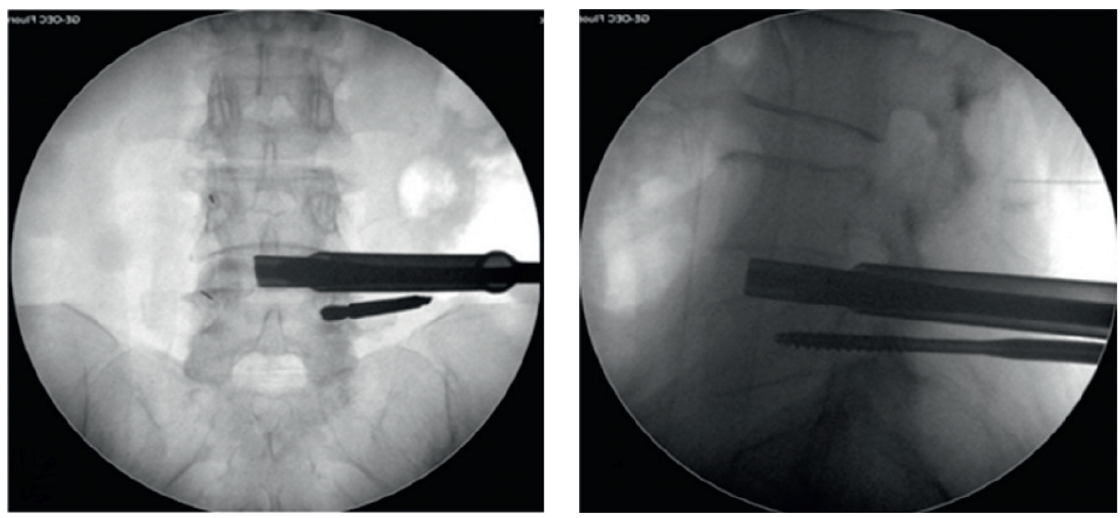

(b)

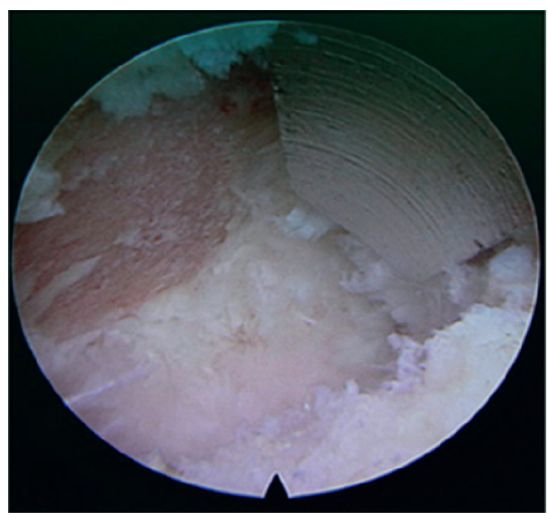

(d)

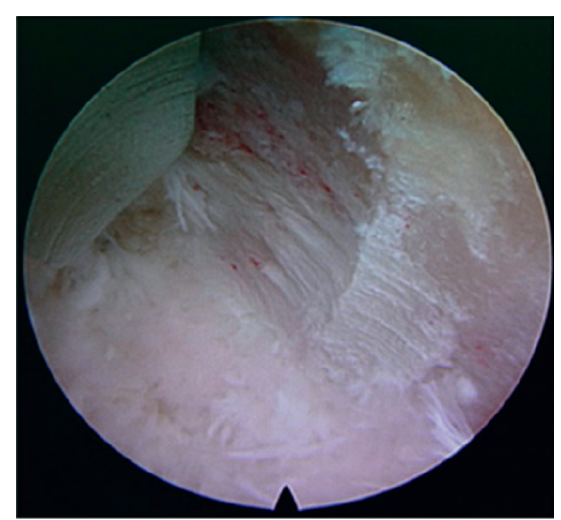

(e)

Figure 4: Endplate preparation. (a) From up to down of the picture, the 15-degree angle endplate curette, the width adjustable reamer, and the bone grafting device. $(b, c)$ The reamer is used to prepare the cartilage endplate to adequately expose the bony endplate. (d, e) The intervertebral space is fully prepared and the appearance of exudation from the bone endplate is good, the bony endplate is fully exposed. The width of the bone graft bed is in a fan-shaped area greater than $13 \mathrm{~mm}$ at the proximal section and $15 \mathrm{~mm}$ at the distal end.

TABLE 1: Comparison of indicators related to efficacy evaluation before and after PE-TLIF.

\begin{tabular}{lccr}
\hline$n=51$ & VAS-LBP & VAS-LP & ODI (\%) \\
\hline Preoperation & $7.22 \pm 0.12$ & $6.24 \pm 0.18$ & $63.28 \pm 2.12$ \\
Post-7d & $3.61 \pm 0.16^{(1)}$ & $2.45 \pm 0.18^{(1)}$ & - \\
Post-1m & $1.24 \pm 0.07^{(1)}$ & $1.22 \pm 0.13^{(1)}$ & $-14.8 \pm 1.10^{(1)}$ \\
Post-3m & $1.06 \pm 0.11^{(1)}$ & $0.98 \pm 0.12^{(1)}$ & $9.00 \pm 0.86^{(1)}$ \\
Final follow-up & $0.67 \pm 0.09^{(1)}$ & $0.41 \pm 0.07^{(1)}$ & \\
\hline
\end{tabular}

Note. (1)Compared with preoperation, $P<0.05$. 

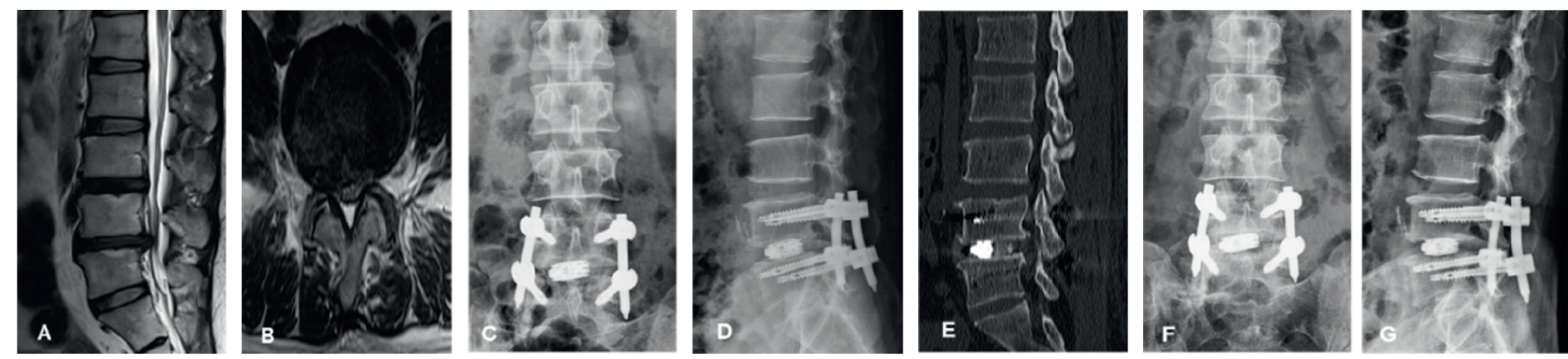

FIGURE 5: A 65-year-old female patient was diagnosed as lumbar spinal stenosis with degenerative instability and was treated by PE-TLIF. (a, b) Preoperative MRI demonstrated a lumbar spinal stenosis at L4/5. (c, d) A good implantation position was presented through X-ray images taken 7 days after the operation. (e) A standard lumbar fusion was presented via CT scan image at 6 months after the operation. (f, $g$ ) $\mathrm{X}$-ray images demonstrated a good implantation position at final follow-up.

TABLE 2: Comparison of indicators related to multifidus injury before and after PE-TLIF.

\begin{tabular}{lccr}
\hline$n=51$ & $\mathrm{CK}(\mathrm{U} / \mathrm{L})$ & $\mathrm{Max}-\mathrm{CSA}\left(\mathrm{mm}^{2}\right)$ & $\mathrm{PI}(\mathrm{db})$ \\
\hline Preoperation & $83.79 \pm 4.99$ & $520.29 \pm 10.27$ & $2.68 \pm 0.11$ \\
Post-1d & $452.62 \pm 13.50^{(1)}$ & - & - \\
Post-7d & $91.23 \pm 2.71^{(2)}$ & $628.20 \pm 11.26^{(1)}$ & $4.55 \pm 0.17^{(1)}$ \\
Post-1m & - & $516.74 \pm 7.86^{(2)}$ & $2.91 \pm 0.06^{2}$ \\
Post-3m & - & $482.29 \pm 8.61^{(2)}$ & $2.53 \pm 0.06^{2}$ \\
Final follow-up & - & $477.42 \pm 8.80^{(2)}$ & $2.36 \pm 0.08^{(2)}$ \\
\hline
\end{tabular}

Note: (1) Compared with preoperation, $P<0.05$; (2) compared with preoperation, $P>0.05$.

TABLE 3: Characteristics of included studies.

\begin{tabular}{|c|c|c|c|c|c|c|c|c|}
\hline First author & $\begin{array}{c}\text { Study } \\
\text { no. }\end{array}$ & Year & $\begin{array}{l}\text { Study } \\
\text { design }\end{array}$ & $\begin{array}{c}\text { No. of } \\
\text { patients }\end{array}$ & $\begin{array}{c}\text { Intraoperative } \\
\text { never monitoring }\end{array}$ & $\begin{array}{l}\text { Anesthesia } \\
\text { method }\end{array}$ & Indication & Follow-up (months) \\
\hline Osman & 1 & 2012 & RS & 60 & Yes & $\begin{array}{c}\text { General } \\
\text { anesthesia }\end{array}$ & $\begin{array}{c}\text { DDD }(8.3 \%), \text { LSS } \\
(81.7 \%), \text { and SL }(10 \%)\end{array}$ & $12(6-25)$ \\
\hline Jacquot & 2 & 2013 & RS & 57 & No & Local anesthesia & DDD $(100 \%)$ & 24 \\
\hline $\mathrm{He}$ & 3 & 2015 & RS & 42 & Yes & $\begin{array}{l}\text { General } \\
\text { anesthesia }\end{array}$ & $\begin{array}{c}\text { LSS (81.0\%), DSL } \\
(14.3 \%), \text { and LDH } \\
(4.8 \%)\end{array}$ & $27.6 \pm 3.8(24-36)$ \\
\hline Morgenstern & 4 & 2015 & RS & 30 & Yes & $\begin{array}{l}\text { General or local } \\
\text { anesthesia }\end{array}$ & $\begin{array}{c}\text { DDD }(30 \%), \text { SL }(40 \%) \\
\text { FA }(20 \%), \text { IAD } \\
(6.67 \%), \text { and CD } \\
(3.33 \%)\end{array}$ & $38 \pm 17(11-67)$ \\
\hline Wang & 5 & 2016 & RS & 10 & Yes & Local anesthesia & $\begin{array}{c}\text { DDD }(100 \%) \text { and SL } \\
(60 \%)\end{array}$ & 12 \\
\hline Lee & 6 & 2017 & RS & 18 & No & Local anesthesia & $\begin{array}{c}\operatorname{DDD}(88.9 \%) \text { and SL } \\
(11.1 \%)\end{array}$ & $46(12-123)$ \\
\hline Heo & 7 & 2017 & RS & 69 & No & $\begin{array}{l}\text { General or } \\
\text { epidural } \\
\text { anesthesia }\end{array}$ & $\begin{array}{c}\text { SL }(87.0 \%) \text { and LSS } \\
(13 \%)\end{array}$ & $13.5 \pm 7.1$ \\
\hline Zhang & 8 & 2017 & RS & 17 & No & $\begin{array}{c}\text { General } \\
\text { anesthesia }\end{array}$ & LSS (100\%) & 12 \\
\hline Myung & 9 & 2018 & RS & None & No & Local anesthesia & None & None \\
\hline Kim & 10 & 2018 & RS & 14 & No & $\begin{array}{c}\text { General } \\
\text { anesthesia }\end{array}$ & $\begin{array}{c}\text { LSS }(57.1 \%) \text { and SL } \\
(42.9 \%)\end{array}$ & 2 \\
\hline $\mathrm{Wu}$ & 11 & 2018 & RS & 7 & Yes & $\begin{array}{c}\text { General } \\
\text { anesthesia }\end{array}$ & SL $(100 \%)$ & $35.1 \pm 3.0(31.5-38.1)$ \\
\hline Yang & 12 & 2019 & RS & 7 & Yes & $\begin{array}{l}\text { Epidural or local } \\
\text { or general } \\
\text { anesthesia }\end{array}$ & LSS (100\%) & $15(12-21)$ \\
\hline John & 13 & 2019 & RS & 100 & No & Local anesthesia & DDD with SL (100\%) & 36 \\
\hline
\end{tabular}


TABLE 3: Continued.

\begin{tabular}{|c|c|c|c|c|c|c|c|c|}
\hline First author & $\begin{array}{l}\text { Study } \\
\text { no. }\end{array}$ & Year & $\begin{array}{l}\text { Study } \\
\text { design }\end{array}$ & $\begin{array}{c}\text { No. of } \\
\text { patients }\end{array}$ & $\begin{array}{c}\text { Intraoperative } \\
\text { never monitoring }\end{array}$ & $\begin{array}{c}\text { Anesthesia } \\
\text { method }\end{array}$ & Indication & Follow-up (months) \\
\hline Park & 14 & 2019 & RS & 71 & No & $\begin{array}{c}\text { General } \\
\text { anesthesia }\end{array}$ & $\begin{array}{c}\text { LSS }(9.9 \%), \text { SL (87.3), } \\
\text { and HNP (2.8) }\end{array}$ & 12 \\
\hline $\mathrm{Wu}$ & 15 & 2020 & RS & 44 & No & Local anesthesia & $\begin{array}{c}\text { LDH }(50 \%) \text { and LSS } \\
(50 \%)\end{array}$ & $13.2 \pm 3.2$ \\
\hline $\mathrm{Wu}$ & 16 & 2020 & RS & 91 & No & Local anesthesia & $\begin{array}{c}\text { LDH or LSS with SL } \\
(100 \%)\end{array}$ & $20.0 \pm 4.1$ \\
\hline Jin & 17 & 2020 & RS & 39 & No & $\begin{array}{l}\text { Epidural or local } \\
\text { anesthesia }\end{array}$ & DLD $(100 \%)$ & $23.6 \pm 4.9(17-28)$ \\
\hline Morgenstern & 18 & 2020 & RS & 51 & No & $\begin{array}{c}\text { Epidural or local } \\
\text { or general } \\
\text { anesthesia }\end{array}$ & $\begin{array}{c}\mathrm{DDD}(84 \%) \text { and } \mathrm{SL} \\
(31 \%)\end{array}$ & $27.9 \pm 27$ \\
\hline Harakuni & 19 & 2020 & RS & 12 & No & $\begin{array}{c}\text { General } \\
\text { anesthesia }\end{array}$ & DDD (100\%) & $6.2(2-10)$ \\
\hline Zhang & 20 & 2020 & RS & 1 & Yes & $\begin{array}{l}\text { General } \\
\text { anesthesia }\end{array}$ & LSS (100\%) & 12 \\
\hline
\end{tabular}

RS: retrospective case series; DDD: degenerative disc disease; DLD: degenerative lumbar disease; LSS: lumbar spinal stenosis; SL: spondylolisthesis; PO: previous operation; DSL: degenerative spondylolisthesis; FA: failed arthrodesis; IAD: instability after decompression; CD: chondroma.

TABLE 4: Interventions and outcomes of included studies.

\begin{tabular}{|c|c|c|c|c|c|c|c|c|}
\hline $\begin{array}{l}\text { Study } \\
\text { no. }\end{array}$ & $\begin{array}{l}\text { Surgical } \\
\text { technique }\end{array}$ & $\begin{array}{l}\text { Resection } \\
\text { of articular } \\
\text { process }\end{array}$ & $\begin{array}{l}\text { Operation time } \\
\text { (minutes) }\end{array}$ & Blood loss (ml) & $\begin{array}{c}\text { Spinal } \\
\text { decompression }\end{array}$ & $\begin{array}{l}\text { Internal } \\
\text { fixation } \\
\text { method }\end{array}$ & $\begin{array}{l}\text { Fusion } \\
\text { rate }\end{array}$ & Complications \\
\hline 1 & Endo-LIF & No & $174(117-251)$ & $57.6(30-100)$ & No & $\begin{array}{c}\text { Bilateral } \\
\text { PS }\end{array}$ & $59.6 \%$ & $\begin{array}{c}8 \text { patients RSE, } 2 \\
\text { patients RN, and } 2 \\
\text { patients PSC }\end{array}$ \\
\hline 2 & PE-TLIF & No & $60 \pm 30$ & None & No & $\begin{array}{l}\text { Bilateral } \\
\text { PS }\end{array}$ & $77 \%$ & $\begin{array}{l}8 \text { patients RPP and } \\
13 \text { patients AMC }\end{array}$ \\
\hline 3 & $\begin{array}{l}\text { FE-MIS- } \\
\text { TLIF }\end{array}$ & Yes & $\begin{array}{l}133.9 \pm 16.1(\mathrm{OS}) \\
241.3 \pm 36.5(\mathrm{TS})\end{array}$ & $\begin{array}{c}221.8 \pm 98.5 \\
(100-550)\end{array}$ & Yes & $\begin{array}{l}\text { Bilateral } \\
\text { PS }\end{array}$ & $92.9 \%$ & 2 patients $\mathrm{PNC}$ \\
\hline 4 & pTLIF & Yes & $\begin{array}{c}120 \pm 30(\mathrm{~A} \text { or } \mathrm{B}) \\
240 \pm 120(\mathrm{C})\end{array}$ & None & No & $\begin{array}{l}\text { Bilateral } \\
\text { PS }\end{array}$ & None & $\begin{array}{c}3 \text { patients TD and } 2 \\
\text { patients SIP }\end{array}$ \\
\hline 5 & E-MIS-TLIF & Yes & $113.5 \pm 6.3(105-120)$ & $\begin{array}{c}65 \pm 38 \\
(30-190)\end{array}$ & Yes & $\begin{array}{c}\text { Bilateral } \\
\text { PS }\end{array}$ & None & No complications \\
\hline 6 & PTLIF & No & $77(62-100)$ & None & No & $\begin{array}{c}\text { Bilateral } \\
\text { PS }\end{array}$ & $88.9 \%$ & $\begin{array}{l}1 \text { patient } \mathrm{PNC}, 1 \\
\text { patient nonunion, } \\
\text { and } 1 \text { patient } \\
\text { revision }\end{array}$ \\
\hline 7 & UBE & Yes & 165 & $85.5 \pm 19.41$ & Yes & $\begin{array}{c}\text { Bilateral } \\
\text { PS }\end{array}$ & None & $\begin{array}{l}2 \text { patients dura tear } \\
\text { and } 3 \text { patients } \\
\text { postoperative } \\
\text { hematoma }\end{array}$ \\
\hline 8 & Endo-TLIF & Yes & $174(130-235)$ & $95(50-200)$ & Yes & $\begin{array}{c}\text { Bilateral } \\
\text { PS }\end{array}$ & $100 \%$ & $\begin{array}{c}2 \text { patients transient } \\
\text { nerve root } \\
\text { paresthesia }\end{array}$ \\
\hline 9 & FELIF & Yes & None & None & Yes & $\begin{array}{c}\text { Bilateral } \\
\text { PS }\end{array}$ & None & None \\
\hline 10 & BE-TLIF & Yes & $169 \pm 10$ & $74 \pm 9$ & Yes & $\begin{array}{c}\text { Bilateral } \\
\text { PS }\end{array}$ & None & $\begin{array}{c}1 \text { patient L5 } \\
\text { paralysis and } 1 \\
\text { patient dura tear }\end{array}$ \\
\hline 11 & PELIF & Yes & $\begin{array}{c}167.5 \pm 30.9 \\
(135-220)\end{array}$ & $\begin{array}{c}70.0 \pm 24.5 \\
(50-100)\end{array}$ & Yes & $\begin{array}{l}\text { Bilateral } \\
\text { PS }\end{array}$ & None & No complication \\
\hline 12 & PE-TLIF & Yes & 285 & $117.1(30-300)$ & Yes & $\begin{array}{c}\text { Bilateral } \\
\text { PS }\end{array}$ & $100 \%$ & $\begin{array}{l}1 \text { patient disc } \\
\text { ruptured and } 1 \\
\text { patient temporary } \\
\text { knee tendon } \\
\text { hyperreflexia }\end{array}$ \\
\hline
\end{tabular}


TABLE 4: Continued.

\begin{tabular}{|c|c|c|c|c|c|c|c|c|}
\hline $\begin{array}{l}\text { Study } \\
\text { no. }\end{array}$ & $\begin{array}{l}\text { Surgical } \\
\text { technique }\end{array}$ & $\begin{array}{l}\text { Resection } \\
\text { of articular } \\
\text { process }\end{array}$ & $\begin{array}{l}\text { Operation time } \\
\text { (minutes) }\end{array}$ & Blood loss (ml) & $\begin{array}{c}\text { Spinal } \\
\text { decompression }\end{array}$ & $\begin{array}{l}\text { Internal } \\
\text { fixation } \\
\text { method }\end{array}$ & $\begin{array}{l}\text { Fusion } \\
\text { rate }\end{array}$ & Complications \\
\hline 13 & $\begin{array}{l}\text { Endoscopic } \\
\text { MIS-TLIF }\end{array}$ & No & $\begin{array}{c}1 \text { level: } 84.5 \pm 21.7 \\
2 \text { levels: } 128.1 \pm 48.6\end{array}$ & $\begin{array}{c}1 \text { level: } \\
65.4 \pm 76.6 \\
2 \text { levels: } \\
74.7 \pm 33.6\end{array}$ & Yes & $\begin{array}{c}\text { Bilateral } \\
\text { PS }\end{array}$ & $100 \%$ & $\begin{array}{l}4 \text { patients convert } \\
\text { to general } \\
\text { anesthesia, } 2 \\
\text { patients cage } \\
\text { migration, 1 patient } \\
\text { osteomyelitis, and 1 } \\
\text { patient endplate } \\
\text { fracture }\end{array}$ \\
\hline 14 & ULIF & Yes & 158 & None & Yes & $\begin{array}{l}\text { Bilateral } \\
\text { PS }\end{array}$ & $\begin{array}{l}25.9 \%(\mathrm{PF}) \\
74.1 \%(\mathrm{DF})\end{array}$ & $\begin{array}{l}3 \text { patients dural } \\
\text { tear, } 1 \text { patient } \\
\text { hematoma, and } 1 \\
\text { patient infection }\end{array}$ \\
\hline 15 & Endo-LIF & Yes & $\begin{array}{l}184.3 \pm 70.6 \\
191.1 \pm 32.4\end{array}$ & $\begin{array}{c}38.5 \pm 19.5 \\
214.6 \pm 61.6\end{array}$ & Yes & $\begin{array}{c}\text { Spinous } \\
\text { process } \\
\text { laminar } \\
\text { screw }\end{array}$ & $95 \%$ & $\begin{array}{l}\text { EG: } 3 \text { patients low } \\
\text { back pain, CG: } 1 \\
\text { patient } \\
\text { cerebrospinal fluid } \\
\text { leakage, and } 1 \\
\text { patient incision } \\
\text { infection }\end{array}$ \\
\hline 16 & MIS-TLIF & Yes & $\begin{array}{l}180.49 \pm 35.19 \\
164.02 \pm 51.91\end{array}$ & $\begin{array}{c}182.00 \pm 106.19 \\
191.30 \pm 93.37\end{array}$ & Yes & $\begin{array}{l}\text { Bilateral } \\
\text { PS }\end{array}$ & None & $\begin{array}{c}\text { EG: No } \\
\text { complication and } \\
\text { CG: } 1 \text { patient } \\
\text { hematoma }\end{array}$ \\
\hline 17 & PELIF & Yes & $\begin{array}{c}213.8 \pm 31.7 \\
(185-324)\end{array}$ & $\begin{array}{c}25.0 \pm 12.6 \\
(15-50)\end{array}$ & Yes & $\begin{array}{l}\text { Bilateral } \\
\text { PS }\end{array}$ & $100 \%$ & $\begin{array}{l}2 \text { patients symptom } \\
\text { was not relieved or } \\
\text { even aggravated, } \\
1 \text { patient disc mass } \\
\text { remnant, } 1 \text { patient } \\
\text { misplacement of L5 } \\
\text { pedicle screw, and } 1 \\
\text { patient } \\
\text { asymptomatic cage } \\
\text { subsidence }\end{array}$ \\
\hline 18 & pTLIF & Yes & None & None & No & $\begin{array}{l}\text { Bilateral } \\
\text { PS }\end{array}$ & None & $\begin{array}{c}12 \text { patients } \\
\text { transitory and } \\
\text { ipsilateral } \\
\text { dysesthesia, } \\
2 \text { patients transitory } \\
\text { and ipsilateral } \\
\text { muscle weakness, } \\
\text { and } \\
3 \text { patients sacroiliac } \\
\text { joint pain }\end{array}$ \\
\hline 19 & PELIF & Yes & $109.4(73-160)$ & None & No & $\begin{array}{l}\text { Bilateral } \\
\text { PS }\end{array}$ & $100 \%$ & $\begin{array}{c}1 \text { patient } \\
\text { paresthesia in both } \\
\text { legs and } \\
1 \text { patient left knee } \\
\text { pain }\end{array}$ \\
\hline 20 & Endo-TLIF & Yes & None & None & Yes & $\begin{array}{l}\text { Bilateral } \\
\text { PS }\end{array}$ & $100 \%$ & No complication \\
\hline
\end{tabular}

CG: control group; VAS: visual analogue scale; RMDQ: Roland-Morris Disability Questionnaire; EG: experiment group; ETD: endoscopic transforaminal decompression; LIF: lumbar interbody fusion; PPSI: percutaneous pedicle screw implantation; RSE: residual discomfort on extension; RN: residual numbness; PSC: pedicle screw-related complications; PE-TLIF: percutaneous endoscopic transforaminal lumbar interbody fusion; RPP: radicular pain with paresthesias; TS: two segments; AMC: asymptomatic migration of the cages: ODI: Oswestry Disability Index; OS: one segment; FE-MIS-TLIF: full-endoscopic minimally invasive transforaminal lumbar interbody fusion; PNC: postoperative neurological complications; PTLIF: percutaneous transforaminal lumbar interbody fusion; TD: transitory dysesthesia; SIP: sacroiliac pain; SF-36: 36-item short form health survey; UBE: unilateral biportal endoscopic technique; DT: dural tear; PEH: postoperative epidural hematoma; BE: biportal endoscopic; PF: probable fusion; DF: definite fusion. 
hemorrhage and edema. Our technique made decisive technical improvements, and the approach could not directly injure the MF. We also chose the percutaneous method to place the screws to avoid injury of the medial branch nerve. Hence, the PE-TLIF technique could minimize the injury of the MF. All the patients obtained satisfactory clinical effects via the evaluation of ODI and VAS, and the postoperative lumbar pain was significantly decreased through our technique. The mean postoperative bedridden time was less than 24 hours in all the patients.

To obtain a comprehensive understanding on endoscopic lumbar interbody fusion, we did a systematic review on endoscopic lumbar interbody fusion for the treatment of lumbar degenerative diseases until December 2020. Finally, 20 studies were included in our present systematic review (SR) $[9,18-36]$. Most studies presented that the endoscopic lumbar fusion technique was a promising treatment for lumbar degenerative diseases, with less muscle injury and quicker rehabilitation. The fusion rate was $59.6 \%-100 \%$, and the complication rate was $0 \%-36 \%$. However, there were no standard operating procedures and specific indications of endoscopic lumbar interbody fusion. More details are listed in Tables 3 and 4 .

To the best of our knowledge, this is the first prospective observational study on MF injury via contrast-enhanced ultrasonography after PE-TLIF for the treatment of patients with LSS and degenerative instability at present. All surgeries were performed by one senior surgeon. Several data on the characteristics of patients and clinical effects were reported in our study. The core part of our innovative technique is to excise the majority of SAP safely and effectively. We innovated a hookshaped front of the cannula, which could be a very useful tool to excise SAP, while could protect soft tissues and nerves. The contradiction on our technique is the severe central type of LSS. However, certain limitations need to be addressed. Our study lacks the conventional control group, and the number of patients is relatively small. More prospective randomized controlled trials are needed to overcome the limitations of our study.

In conclusion, our results and SR presented the innovative PE-TLIF technique could obtain satisfactory and effective outcomes for the treatment of patients with LSS and degenerative instability. Our PE-TLIF technique also had the ability to decrease MF injury. Patients with PE-TLIF could have a quicker postoperative rehabilitation.

\section{Data Availability}

The data used to support the findings of this study are available from the corresponding author upon request.

\section{Disclosure}

The trial registration number is ChiCTR1900020679. The small parts of involved items have been published in a preprint [37].

\section{Conflicts of Interest}

The authors declare that they have no conflicts of interest.

\section{Authors' Contributions}

Peng Yin and Haifeng Gao contributed equally to the study.

\section{Acknowledgments}

This work was supported by a Shoufa grant (2020-2-2038) and an innovation grant of National Clinical Research Center for Orthopedics, Sports Medicine \& Rehabilitation (2021-NCRC- CXJJ-PY-34).

\section{References}

[1] A. A. Cole, "Fusion for lumbar spinal stenosis?" BMJ, vol. 353, p. i3145, 2016.

[2] M. Tsubosaka, S. Kaneyama, T. Yano et al., "The factors of deterioration in long-term clinical course of lumbar spinal canal stenosis after successful conservative treatment," Journal of Orthopaedic Surgery and Research, vol. 13, no. 1, p. 239, 2018.

[3] M. R. Farrokhi, G. Yadollahikhales, M. Gholami, S. R. Mousavi, A. R. Mesbahi, and A. A. Asadi-Pooya, "Clinical outcomes of posterolateral fusion vs. Posterior lumbar interbody fusion in patients with lumbar spinal stenosis and degenerative instability," Pain Physician, vol. 21, no. 4, pp. 383-406, 2018.

[4] C. L. Goldstein, K. Macwan, K. Sundararajan, and Y. R. Rampersaud, "Perioperative outcomes and adverse events of minimally invasive versus open posterior lumbar fusion: meta-analysis and systematic review," Journal of Neurosurgery: Spine, vol. 24, no. 3, pp. 416-427, 2016.

[5] N. Shafaq, A. Suzuki, A. Matsumura et al., "Asymmetric degeneration of paravertebral muscles in patients with degenerative lumbar scoliosis," Spine (Phila Pa 1976), vol. 37, no. 16, pp. 1398-1406, 2012.

[6] J. C. Lee, J. G. Cha, Y. Kim, Y. I. Kim, and B. J. Shin, "Quantitative analysis of back muscle degeneration in the patients with the degenerative lumbar flat back using a digital image analysis: comparison with the normal controls," Spine (Phila Pa 1976), vol. 33, no. 3, pp. 318-325, 2008.

[7] M. D. Freeman, M. A. Woodham, and A. W. Woodham, "The role of the lumbar multifidus in chronic low back pain: a review," PM\&R, vol. 2, no. 2, pp. 142-146, 2010.

[8] S.-M. Cho, S.-H. Kim, S.-K. Ha et al., "Paraspinal muscle changes after single-level posterior lumbar fusion: volumetric analyses and literature review," BMC Musculoskeletal Disorders, vol. 21, no. 1, p. 73, 2020.

[9] J. L. Yang, C. Hai, Y. Yin et al., "Percutaneous endoscopic transforaminal lumbar interbody fusion for the treatment of lumbar spinal stenosis: preliminary report of seven cases with 12-month follow-up," BioMed Research International, vol. 2019, Article ID 3091459, 2019.

[10] L. Hansen, M. de Zee, J. Rasmussen, T. B. Andersen, C. Wong, and E. B. Simonsen, "Anatomy and biomechanics of the back muscles in the lumbar spine with reference to biomechanical modeling," Spine (Phila Pa 1976), vol. 31, no. 17, pp. 18881899, 2006.

[11] T. Tsutsumimoto, M. Shimogata, H. Ohta, and H. Misawa, "Mini-open versus conventional open posterior lumbar interbody fusion for the treatment of lumbar degenerative spondylolisthesis: comparison of paraspinal muscle damage and slip reduction," Spine (Phila Pa 1976), vol. 34, no. 18, pp. 1923-1928, 2009. 
[12] T. Sihvonen, A. Herno, L. Paljärvi, O. Airaksinen, J. Partanen, and A. Tapaninaho, "Local denervation atrophy of paraspinal muscles in postoperative failed back syndrome," Spine (Phila Pa 1976), vol. 18, no. 5, pp. 575-581, 1993.

[13] J. D. Schwender, L. T. Holly, D. P. Rouben, and K. T. Foley, "Minimally invasive transforaminal lumbar interbody fusion (TLIF): technical feasibility and initial results," Journal of Spinal Disorders \& Techniques, vol. 18, no. Suppl, pp. S1-S6, 2005.

[14] G. J. Regev, Y. P. Lee, W. R. Taylor, S. R. Garfin, and C. W. Kim, "Nerve injury to the posterior rami medial branch during the insertion of pedicle screws: comparison of miniopen versus percutaneous pedicle screw insertion techniques," Spine (Phila Pa 1976), vol. 34, no. 11, pp. 1239-1242, 2009.

[15] Y. Kawaguchi, H. Matsui, and H. Tsuji, "Changes in serum creatine phosphokinase MM isoenzyme after lumbar spine surgery," Spine (Phila Pa 1976), vol. 22, no. 9, pp. 1018-1023, 1997.

[16] S.-w. Fan, Z.-j. Hu, X.-q. Fang, F.-d. Zhao, Y. Huang, and $\mathrm{H}$.-j. Yu, "Comparison of paraspinal muscle injury in onelevel lumbar posterior inter-body fusion: modified minimally invasive and traditional open approaches," Orthopaedic Surgery, vol. 2, no. 3, pp. 194-200, 2010.

[17] H.-f. Zhu, G.-l. Wang, Z.-j. Zhou, and S.-w. Fan, "Prospective study of long-term effect between multifidus muscle bundle and conventional open approach in one-level posterior lumbar interbody fusion," Orthopaedic Surgery, vol. 10, no. 4, pp. 296-305, 2018.

[18] T. Harakuni, H. Iwai, Y. Oshima et al., "Full-endoscopic lumbar interbody fusion for treating lumbar disc degeneration involving disc height loss: technical report," Medicina (Kaunas, Lithuania), vol. 56, no. 9, 2020.

[19] E.-x. He, J. Guo, Q.-j. Ling, Z.-x. Yin, Y. Wang, and M. Li, "Application of a narrow-surface cage in full endoscopic minimally invasive transforaminal lumbar interbody fusion," International Journal of Surgery, vol. 42, pp. 83-89, 2017.

[20] D. H. Heo, S. K. Son, J. H. Eum, and C. K. Park, "Fully endoscopic lumbar interbody fusion using a percutaneous unilateral biportal endoscopic technique: technical note and preliminary clinical results," Neurosurgical Focus, vol. 43, no. 2, p. E8, 2017.

[21] F. Jacquot and D. Gastambide, "Percutaneous endoscopic transforaminal lumbar interbody fusion: is it worth it?" International Orthopaedics, vol. 37, no. 8, pp. 1507-1510, 2013.

[22] M. Jin, J. Zhang, H. Shao, J. Liu, and Y. Huang, "Percutaneous transforaminal endoscopic lumbar interbody fusion for degenerative lumbar diseases: a consecutive case series with mean 2-year follow-up," Pain Physician, vol. 23, no. 2, pp. 165-174, 2020.

[23] J.-E. Kim and D.-J. Choi, "Biportal endoscopic transforaminal lumbar interbody fusion with arthroscopy," Clinical Orthopaedic Surgery, vol. 10, no. 2, pp. 248-252, 2018.

[24] J. P. G. Kolcun, G. D. Brusko, G. W. Basil, R. Epstein, and M. Y. Wang, "Endoscopic transforaminal lumbar interbody fusion without general anesthesia: operative and clinical outcomes in 100 consecutive patients with a minimum 1-year follow-up," Neurosurgical Focus, vol. 46, no. 4, p. E14, 2019.

[25] S. H. Lee, H. Y. Erken, and J. Bae, "Percutaneous transforaminal endoscopic lumbar interbody fusion: clinical and radiological results of mean 46-month follow-up," BioMed Research International, vol. 2017, Article ID 3731983, 9 pages, 2017.
[26] C. Morgenstern, J. J. Yue, and R. Morgenstern, "Full percutaneous transforaminal lumbar interbody fusion using the facet-sparing, trans-kambin approach," Clinical Spine Surgery: A Spine Publication, vol. 33, no. 1, pp. 40-45, 2020.

[27] R. Morgenstern and C. Morgenstern, "Percutaneous transforaminal lumbar interbody fusion (pTLIF) with a posterolateral approach for the treatment of degenerative disk disease: feasibility and preliminary results," International Journal of Spine Surgery, vol. 9, p. 41, 2015.

[28] S. G. Osman, "Endoscopic transforaminal decompression, interbody fusion, and percutaneous pedicle screw implantation of the lumbar spine: a case series report," The International Journal of Spine Surgery, vol. 6, no. 1, pp. 157-166, 2012.

[29] M.-K. Park, S.-A. Park, S.-K. Son, W.-W. Park, and S.-H. Choi, "Clinical and radiological outcomes of unilateral biportal endoscopic lumbar interbody fusion (ULIF) compared with conventional posterior lumbar interbody fusion (PLIF): 1-year follow-up," Neurosurgical Review, vol. 42, no. 3, pp. 753-761, 2019.

[30] M. Y. Wang and J. Grossman, "Endoscopic minimally invasive transforaminal interbody fusion without general anesthesia: initial clinical experience with 1-year follow-up," Neurosurgical Focus, vol. 40, no. 2, p. E13, 2016.

[31] J. Wu, H. Liu, S. Ao et al., "Percutaneous endoscopic lumbar interbody fusion: technical note and preliminary clinical experience with 2-year follow-up," BioMed Research International, vol. 2018, Article ID 5806037, 2018.

[32] J. Wu, C. Zhang, K. Lu, C. Li, and Y. Zhou, "A novel inextensible endoscopic tube versus traditional extensible retractor system in single-level minimally invasive transforaminal lumbar interbody fusion: a prospective observation study," Pain Physician, vol. 22, no. 6, pp. E587-e599, 2019.

[33] W. Wu, S. Yang, W. Diao et al., "Analysis of clinical efficacy of endo-LIF in the treatment of single-segment lumbar degenerative diseases," Journal of Clinical Neuroscience, vol. 71, pp. 51-57, 2020.

[34] M. S. Youn, J. K. Shin, T. S. Goh, and J. S. Lee, "Full endoscopic lumbar interbody fusion (FELIF): technical note," European Spine Journal, vol. 27, no. 8, pp. 1949-1955, 2018.

[35] Y. Zhang, C. Xu, Y. Zhou, and B. Huang, "Minimally invasive computer navigation-assisted endoscopic transforaminal interbody fusion with bilateral decompression via a unilateral approach: initial clinical experience at one-year follow-up," World Neurosurgery, vol. 106, pp. 291-299, 2017.

[36] Y. W. Zhang, W. H. Xia, W. C. Gao, X. Xiao, Y. Xiao, and F. P. Gong, "Direct foraminoplasty in endoscope-assisted transforaminal lumbar interbody fusion for the treatment of lumbar disc herniation," Journal of International Medical Research, vol. 48, no. 1, Article ID 300060519875372, 2020.

[37] P. Yin, Y. Ding, L. J. Zhou et al., An Innovative Percutaneous Endoscopic Transforaminal Lumbar Interbody Fusion for the Treatment of Lumbar Spinal Stenosis with Degenerative Instability: A Prospective Cohort Study, https://www. researchsquare.com/article/rs-148627/v1. 